\title{
Time-lapse resistivity investigation of salinity changes at an ex-promontory land: a case study of Carey \\ Island, Selangor, Malaysia
}

\author{
Mohamad Faizal Tajul Baharuddin - Samsudin Taib · \\ Roslan Hashim - Mohd Hazreek Zainal Abidin · \\ Mohd Fakhrurrazi Ishak
}

Salinity of groundwater aquifers, especially at

coastal regions, changes naturally or through human

activity. A major cause, sometimes affecting

freshwater quality, is seawater intrusion. Excessive

withdrawing of groundwater, and significant decrease in recharge, too, contribute (Pujari and

Soni 2008). Aquifer-salinity changes naturally

when low-density fresh groundwater interacts

with high-density saltwater. The best geophysical

method, particularly in salinity mapping, is

geo-electrical method (Loke 2010a). Researchers

demarcating coast hydrogeology have been using

geo-electrical method to map salinity ever

since development of the interpretation technique

by Loke and Barker (1996). Electrical resistivity

method is unique as it detects increased aquifer

conductivity via increased pore-water conductivity

(Abdul Nassir et al. 2000). Benkabbour et al.

(2004) used geophysical method to characterize

saltwater intrusion in the Plioquaternary consolidated

coastal aquifer of the Mamora Plains,

Morocco. Di Sipio et al. (2006) used geo-electrical method and geochemistry data to get better salinity

profile of the groundwater system in Venice

estuaries. Awni (2006) used 2-D geo-electrical

method to detect subsurface freshwater and saline

water at the alluvial shoreline of the Dead 
Sea, Jordan. Sherif et al. (2006) integrated geoelectrical

method with hydro-geochemical method

to delineate saltwater intrusion at Wadi Ham,

UAE. In Lagos, Nigeria, Adepelumi et al. (2009)

used vertical-electrical-sounding survey to delineate

Lekki Peninsula freshwater-aquifer saltwater

Intrusion

The studies detected and mapped salinity at

regions of spatial variations. Salinity changes are

dynamic, happening every day in groundwater

systems, especially at open-sea coastal, and estuarine,

regions. Major factors relating to time and space are tide, season, and seawater density.

Geo-electric imaging surveys of space have been

done, and can be done for time (Loke 2010a).

Image analysis, from spatially distributed resistances

at specific time intervals, is through timelapse

electrical-resistivity tomography (TLERT).

TLERT's various applications have attracted

many researchers: Barker and Moore (1998) for

physical-model tests of groundwater flow and contamination;

Kemna et al. (2002), Cassiani et al.

(2006), and Oldenborger et al. (2007) for tracertest

study of aquifers; Olofsson and Lundmark

(2009) for impact monitoring of roadside-soil

de-icing-salt in saltwater investigation; and Ogilvy

et al. (2009) for study of near-coast saltwater intrusion;

in each, TLERT images relate change in

salinity to transport of solutes.

TLERT is capable of minimal-invasionmonitoring

of hydraulic processes in porous media

by capturing temporal conductivity variations

(Ogilvy et al. 2009). TLERT measurements fill,

less expensively, gaps in data on space between

sets of boreholes (Maillet et al. 2005). Acquisition

of TLERT-image resistance data requires good

electrical grounding during TLERT monitoring. 
Soil electrical conductivity is influenced by the complex interaction among soil's physical properties, water content, salinity, and ground temperature, all possibly influencing electrical grounding (Olofsson and Lundmark 2009). Poor electrical grounding disables data acquisition, resulting in incomplete resistivity data. Good electrical grounding takes time to prepare, but without it, image quality is affected, and the rate of change that can be captured with TLERT monitoring becomes limited. Discussed here are resistivity-acquisition techniques where poor electrical grounding is improved.

This work's concern is salinity changes to freshwater

at Carey Island in the state of Selangor,

Malaysia (Fig. 1). Carey Island, near Indah Island, is Malaysia's biggest trading port. Not only is it located in Malaysia's most advanced industrial and trading state (Selangor), it is also near Malaysia's administration centers of Putrajaya and Kuala Lumpur (capital city of Malaysia). Its infrastructure has grown rapidly, with highways mobilizing trade between it and South Peninsular Malaysia. Its population is expected to increase significantly when its entire infrastructure had been completed.

Selangor was predicted to be 1 million m3of water short daily in 2007 (Tahir and Abdul Hamid 2003). At Carey Island, the shortage was regular, so people harvested rain. Government agencies such as the Department of Mineral and Geo- 


\begin{tabular}{|l|l|}
\hline$E-C$ & clay \\
\hline & Sond \\
$\varnothing \varnothing$ & Peaty \\
$\triangle \Omega$ & Shell \\
\hline
\end{tabular}

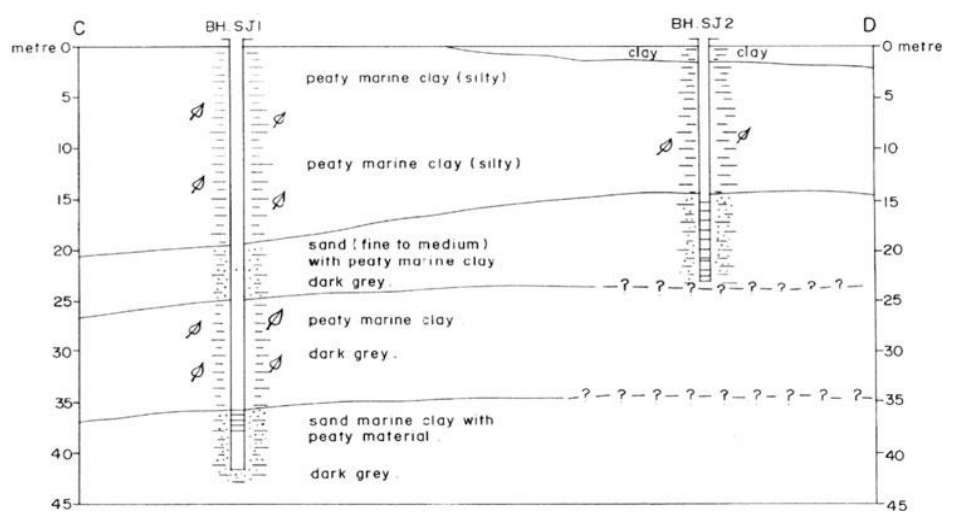

Fig. 2 Sg. Judah Village subsurface profile and geochemistry data at semi-confined aquifer (Ngah 1988)

Science were asked to determine the island's water-supply potential. On the district council's request, Ngah (1988) investigated groundwater at five aboriginal villages to determine shallowaquifer potential (Fig. 1). Sg. Judah study revealed freshwater in aquifers less than $25 \mathrm{~m}$ deep. Thicknesses of semi-confined aquifers ranged between 5 and $7 \mathrm{~m}$ (Fig. 2). Some shallow semi-confined aquifers there especially at borehole SJ3 $400 \mathrm{~m}$ south of borehole SJ2 was identified as having brackish water, chloride concentration $620 \mathrm{mg} / \mathrm{l}$ (Fig. 3). Aquifers more than $35 \mathrm{~m}$ deep were identified as not having promising groundwater potential because saline and brackish waters were more dominant. Tahir and Abdul Hamid continued investigations in 2003 , as requested by the Malaysian Government and provisioned in the Eighth Malaysia Plan (2000-2005) for northern region. They revealed brackish-water domination, chloride concentration $>250 \mathrm{mg} / \mathrm{l}$, still, in groundwater $95 \mathrm{~m}$ deep. In 2008, Ismail furthered the study, encountering screen level at depths between 175 and $180 \mathrm{~m}$; no potential for groundwater extraction (the groundwater was dominated by brackish water, conductivity value $>2,000 \mu \mathrm{S} / \mathrm{cm}$ ). 
Preceding effort was to understand the area's hydrogeology

so its groundwater-exploration could

be strategized. Efforts by relevant government

agencies to identify the best strategy have been

unsuccessful.

This study used TLERT at an ex-promontory

land: Carey Island. It identified (via boreholedata,

hydro-geochemistry analysis, and landtransformation

history) changes in salinity of the

tropical island's coastal aquifer system. Its results

based a strategy for groundwater exploration of

the island.

Full text available at :

http://download.springer.com/static/pdf/732/art\%253A10.1007\%252Fs10661-010-1792-

x.pdf?auth66=1387434611 0d2076ff93d8b853aa864804245b81f4\&ext=.pdf

http://link.springer.com/article/10.1007/s10661-010-1792-x 